SECTION 21. Pedagogy. Psychology. Innovations in the field of education.

Yunusova Guzal Sultanovna

Head of Department, the Institute of Teachers' Training and Professional Development, Fergana,

Uzbekistan

\title{
THE RESULT OF IMAGINES OF THE YOUTH AND TEENAGERS WHO BRINGINGUP IN PLENITABLE AND UNPLENITABLE FAMILY
}

The article considers the issues of education of adolescents in the family.

Keywords: education, family.

The orientation of traditions" of M.Rokich's methods of relations of youth and teenagers to family traditions are translated to Uzbek. By this method, the youth and teenagers from plenitable and unplenitable family are tested and they give order to estimate the value of the family traditions.

As we know, M.Rokich prefers 2 groups, of methods the first one consists of phrases, the second, is instrumental, and consists of key words. In spite of, the investigation was very difficult, we tried to hold it between youth and teenagers and they must value the place of the family traditions.

As the result, we choose the methods of traditions and don't change the style of author. Because, the main problem is to choose social group of traditions. During looking through the result of investigation we keep the principles, the youth and teenagers marks from 18 traditions 10 positions and separate the marked traditions. On the 1st scheme you can see the result of girls from unplenitable family in the block $\mathrm{A}$ ". For example, from 90 plenitable family"s member put 1 to salomatlik" and we divided it to 90 . You can see it on the scheme №1.

Scheme №1

The value of the youth and teenager girls from unplentable family (block A) $\mathrm{N}=176$

\begin{tabular}{|l|c|c|l|c|c|}
\hline \multirow{2}{*}{ Traditions } & \multicolumn{2}{|c|}{$\begin{array}{c}\text { Girls from } \\
\text { plenitable family } \\
\text { (N=90) }\end{array}$} & \multirow{2}{*}{ Traditions } & \multicolumn{2}{c|}{$\begin{array}{c}\text { Girls from } \\
\text { unplenitable } \\
\text { family (N=86) }\end{array}$} \\
\cline { 2 - 3 } \cline { 5 - 6 } & Abs & Coif & & Abs & Coif \\
\hline 1.Health & 71 & 78,8 & 1.Health & 80 & 93,0 \\
\hline 2.Funny life & 53 & 58,9 & $\begin{array}{l}\text { 2. Financially } \\
\text { security }\end{array}$ & 72 & 83,7 \\
\hline 3. Business luck & 52 & 57,8 & 3.Experience & 70 & 81,4 \\
\hline 4.Love & 40 & 44,4 & 4. Funny life & 50 & 58,1 \\
\hline 5.Freedom & 33 & 36,7 & 5.Independence & 49 & 57,0 \\
\hline
\end{tabular}




\begin{tabular}{|c|c|c|c|c|c|}
\hline $\begin{array}{l}\text { 6.Happy family } \\
\text { life }\end{array}$ & 32 & 35,6 & 6. Business luck & 44 & 51,2 \\
\hline $\begin{array}{l}\text { 7.To have good } \\
\text { position in social } \\
\text { life }\end{array}$ & 31 & 34,4 & 7.Happy family life & 43 & 50,0 \\
\hline 8.Independence & 25 & 27,8 & 8.Spirit fullness & 43 & 50,0 \\
\hline $\begin{array}{l}\text { 9.Financially } \\
\text { security }\end{array}$ & 23 & 25,6 & $\begin{array}{l}\text { 9.Happines of } \\
\text { member's of family }\end{array}$ & 33 & 38,4 \\
\hline 10.Wide sense & 17 & 18,9 & $\begin{array}{l}\text { 10.The soft life in } \\
\text { old hood }\end{array}$ & 20 & 23,3 \\
\hline
\end{tabular}

As you see on the scheme, the main tradition of the life for the girls from two groups was the health. Many girls marked it with №1, especially, for the girls from plenitable family this tradition differ in each group. For example, the girls from plenitable family prefer the funny life, the luck on business and others prefer money fullness to funny life. $(83,7)$ Experience $(81,4)$. Funny life" differ for 58,9 to 58,1 mark between two groups, but, stay on the $4^{\text {th }}$ place. So, as you see below two groups mark the traditions such as business luck" (57,8 and 51,2), happy life $(35,6$ and 50,0) independence" (27,8 and 57,0), money fullness $(25,6$ and 83,7$)$. If you pay attention to the tradition -money fullness", it differs between the girls from other families. $(25,6$ and 83,7$)$.

In the next period we hold the experiments for instrumental traditions.

Scheme №2

The result of marks of the youth and teenager girls from the plenitable and unplenitable family (block B) $\mathrm{N}=176$

\begin{tabular}{|c|c|c|c|c|c|}
\hline \multirow[t]{2}{*}{ Traditions } & \multicolumn{2}{|c|}{$\begin{array}{c}\text { Girls from } \\
\text { plenitable family } \\
(\mathrm{N}=90)\end{array}$} & \multirow[t]{2}{*}{ Traditions } & \multicolumn{2}{|c|}{$\begin{array}{c}\text { Girls from } \\
\text { unplenitable } \\
\text { family }(\mathrm{N}=86)\end{array}$} \\
\hline & Abs & Coif & & Abs & Coif \\
\hline 1.Intelegence & 27 & 30,0 & 1.Moral & 66 & 76,7 \\
\hline 2.strong hope & 25 & 27,8 & 2.Modesty & 62 & 72,1 \\
\hline 3.bringing up & 20 & 22,2 & 3.To control herself & 50 & 58,1 \\
\hline 4.be funny & 20 & 22,2 & 4. Funny life & 48 & 55,8 \\
\hline $\begin{array}{l}\text { 5.to have own } \\
\text { opinion }\end{array}$ & 18 & 20,0 & 5.the wide view & 40 & 46,5 \\
\hline 6.the wide view & 17 & 18,9 & 6.the result of work & 34 & 39,5 \\
\hline 7.modesty & 16 & 17,8 & 7.be funny & 31 & 36,05 \\
\hline $\begin{array}{l}\text { 8.the result of } \\
\text { work }\end{array}$ & 15 & 16,7 & 8.bringing up & 23 & 26,7 \\
\hline 9.moral & 13 & 14,4 & 9.intelegence & 23 & 26,7 \\
\hline 10.responsibility & 10 & 11,1 & $\begin{array}{l}\text { 10.to have own } \\
\text { opinion }\end{array}$ & 10 & 11,6 \\
\hline
\end{tabular}


On the scheme, we can see that the person want to have such traditions. Block B is the high marked value of the experiment and Block A; you can see the similar qualities. Because, among traditions every group choose 8 similar traditions, but put in different place.

For example, the intelligence", stay in the $1^{\text {st }}$ place for the girls of plenitable family, (30.0) but the girls put it to the 9th place (26.7). Well furnished -stays on the $1^{\text {st }}$ place of the girls from the unplenitable family (76.7) and it stays on the 9th place of girls from the plenitable family (14.4). While we were investigating the girls from the plenitable family, we showed the similarities among the answers. Their very popular answers were well furnished", -modesty", to control herself - justice". The girls from plenitable family have intellectual tendency to -knowledge"," strong hope", good behavior", - Funny" and they have not general meaning , but have low coefficient .Because, 25 of them behavior and give the $2^{\text {nd }}$ place. In unplenitable families 23 of the girls considers these units, but give the $8^{\text {th }}$ place. Generally, you can see the principles between 2 families.

If we begin to discuss the differences between two families, the plenitable family's representative prefers -strong hope" and responsibility" don 't have the place among ten places. We understand that the social life relates to the youth and teenager girls.

The youth and teenager bay from the plenitable and unplenitable family differs from the point of the view of teenager girls. For example, if the girls value the health" as the main traditions, the boys give 1 and put on the $7^{\text {th }}$ place and differs 78,9 to 93,0 (girls) 76,0 to 53,1 (boys).

Scheme №3

The results of the value of life tradition among the youth and teenager boy from the plenitable and unplenitable family (block $A)(N=99)$

\begin{tabular}{|c|c|c|c|c|c|}
\hline \multirow[t]{2}{*}{ Traditions } & \multicolumn{2}{|c|}{$\begin{array}{l}\text { Girls from } \\
\text { plenitable family } \\
(\mathrm{N}=50)\end{array}$} & \multirow[t]{2}{*}{ Traditions } & \multicolumn{2}{|c|}{$\begin{array}{c}\text { Girls from } \\
\text { unplenitable } \\
\text { family }(\mathrm{N}=49)\end{array}$} \\
\hline & Abs & Coif & & Abs & Coif \\
\hline 1.Happy life & 39 & 78.0 & $\begin{array}{l}\text { 1.Economic } \\
\text { profuseness }\end{array}$ & 41 & 83.7 \\
\hline 2.Health & 38 & 76.0 & 2. Freedom & 40 & 81.6 \\
\hline 3.Freedom & 34 & 68.0 & 3. Trust to itself & 33 & 67.35 \\
\hline $\begin{array}{l}\text { 4.To be active in } \\
\text { job }\end{array}$ & 28 & 56.0 & 4. Happy life & 32 & 65.3 \\
\hline 5.Happines & 25 & 50.0 & 5.To have own place & 30 & 61.2 \\
\hline 6.Love & 24 & 48.0 & 6. Independence & 27 & 55.1 \\
\hline $\begin{array}{l}\text { 7.To have best } \\
\text { friend }\end{array}$ & 24 & 48.0 & 7.Health & 26 & 53.1 \\
\hline 8.Full life & 20 & 40.0 & 8.Experience & 22 & 44.9 \\
\hline
\end{tabular}




\begin{tabular}{|l|l|l|l|l|l|}
\hline 9.Independence & 17 & 34.0 & 9.Happinee & 21 & 42.9 \\
\hline 10.Beliefe & 16 & 32.0 & 10.Spiritual progress & 18 & 36.7 \\
\hline
\end{tabular}

As we see on the scheme, the happy family life" 78,0 stays on the $1^{\text {st }}$ place of the teenager boys from the plenitable family, but - mney fullness $(83,7)$ ", to live happy $(65,3)$ ", stay in the next place of the boys from unplenitable family. Health", (76,0 to 53,1), Independence" $(68,0$ to 81,6$)$, Happiness of members" (50,0 to 42,9), Independence" $(34,0$ to 55,1), Belief" $(32,0$ to 67,35$)$ have the main position in this retting, but the coefficient differs. For example, when we analyze he boys from the unplenitable family, we consider that they will be good person and father in future. Half of representatives prefer teacher the children to be modesty.

The boys from the unplenitable family value the modesty, to control himself as the positive category, but the boy from another family value these category on the last place.

\section{REFERENCE}

1. Abdusattorova O.A.. Oila muhitida o'smirlarda shakllanadigan identifikatsiyaning gender xususiyatlari // Psixol.f.n. ilmiy daraja. olish uchun yozilgan diss. avtoref.-T., UzMU 2007. -22 b.

2. Gender tadqiqoti asoslari kursi xrestomatiyasi: Oliy o'quv yurtlari uchun tavsiya qilinqdi // Ilmiy muharrir: prof. $\mathrm{O}^{\prime}$.Abilov; Rus tilidan qisqartirilgan tarjima: dots. 3.Boboeva, 3.Usmonova. - T.: O'zbekiston, 2003. - 276 b.

3. Golod S.I. Stabilnost' sem'i: sotsiologicheskiy i demograficheskiy aspekti/Pod red. G.M.Romanenkovoy.-L.,1984.-136 s.

4. Drujinin V.N. Psixologiya sem'i: 3-e izd. - SPb: Piter, 2008

5. Imom G'azolliy. Ey, farzand. - T.: Movarounnaxr, $2005-128$ b.

6. Eydemiller E.G. Yustiskiy V.V. Semeynaya psixoterapiya. - L., 1989. - 192s.

7. Karimova V.M.Yoshlarda o'zbek oilasi to 'g'risidagi tasavvurlar/ Psixol.f.d. ilmiy darajasini olish uchun yozilgan dis.. Farg'ona.: FDU 1994.-291 b.

8. Karimov I. A. Yuksak ma'naviyat - engilmas kuch.- T.:Ma'naviyat, 2008-54 b.

9. Kon I.S. Psixologiya yunesheskogo vozrasta: (Problemi formirovaniya lichnosti). Ucheb. posobie dlya studentov ped. in-tov. - M.: Prosveshenie, 1979. - $175 \mathrm{~s}$. 